\title{
Molecular Cytogenetic Organization of 5S and 18S rDNA Loci in Aster ageratoides var. ageratoides, A. iinumae (=Kalimeris pinnatifida) and A. microcephalus var. ovatus in Japan
}

\author{
Hideyuki Matoba, ${ }^{1}$ Akiko Soejima, ${ }^{2, *}$ Yoshikazu Hoshi ${ }^{1}$ \\ and Katsuhiko Kondo ${ }^{3}$
}

\footnotetext{
${ }^{1}$ Department of Plant Science, Kyushu Tokai University, Choyo-son, Aso-gun, Kumamoto, 869-1404, Japan

${ }^{2}$ School of Science, University of Osaka Prefecture, Sakai, 599-8531 Japan

${ }^{3}$ Laboratory of Plant Chromosome and Gene Stock, Graduate of Science, Hiroshima University, HigashiHiroshima 739-8526, Japan
}

Received June 30, 2005; accepted August 23, 2005

\begin{abstract}
Summary Detailed karyotypes of diploid Aster ageratoides var. ageratoides $(2 n=18)$, diploid $A$. iinumae (=Kalimeris pinnatifida) $(2 n=18)$ and tetraploid A. microcephalus var. ovatus $(2 n=36)$ were constructed on the basis of chromosome lengths, arm ratios and multi color fluorescence in situ hybridization (McFISH) with 5S and 18S ribosomal RNA gene sequences as probes. The karyotype of A. iinumae was morphologically similar to those of A. ageratoides var. ageratoides, however, the size of the chromosomes of $A$. iinumae was apparently smaller (S-type chromosomes) compared to those of $A$. ageratoides (L-type chromosomes). The chromosomes of $A$. microcephalus var. ovatus, a putative amphidiploid between them consisted of the 18 large chromosomes (L-type chromosomes) and the 18 smaller chromosomes (S-type chromosomes). The McFISH with 5S rDNA and 18S rDNA of each $A$. ageratoides and $A$. iinumae chromosomes tagged 4 out of 18 chromosomes. Whereas A. microcephalus var. ovatus have $5 \mathrm{~S}$ rDNA and $18 \mathrm{~S}$ rDNA sites equal to the sum of the numbers in the two diploids (A. ageratoides and A. iinumae), 4 on the L-type chromosomes and 4 on the S-type chromosomes. The locations of the rDNA sites in A. microcephslus var. ovatus are corresponding to those of $A$. ageratoides and $A$. iinumae.
\end{abstract}

Key words Ag-NOR, Aster s.l., Asteraceae, Chromosome evolution, 18S rDNA, 5S rDNA, Kalimeris, Karyotype analysis, McFISH.

Aster L. is one of the representative genera of the family Asteraceae, which is well-known as distributed widely in Eurasia (Richard and Rieseberg 1999). But the generic circumscription of Eurasian Aster has been still controversial because of the existence of many closely related genera (Bremer 1994). In the Eastern Asia, three small genera, Kalimeris Cass., Heteropappus Less., and Miyamayomena Kitamura (=Gymnaster Kitamura) were segregated from Aster by Kitamura (1937), primarily based on the length of the pappus. However, molecular works of Ito et al. (1995 and 1998) showed that Kalimeris and Miyamayomena have multiple origins respectively, each derived from different ancestors of Aster, and Heteropappus from another species of Aster. In conclusion, they suggested that these three genera and Aster sensu strict should be merged together to form Aster sensu lato. Their results indicated that the length of the pappus could have been shortened independently in parallel evolution. But what is more interesting evolutionary trend they showed was the direction of chromosome evolution. Previous studies (Huziwara 1957a,b, 1958, 1967, Shindo 1967) have revealed that some species of Kalimeris had karyotype consisted of signif-

* Corresponding author, e-mail: soejima@b.s.osakafu-u.ac.jp 
icantly small chromosomes (S-type karyotype) comparing to those of other species of Japanese Aster s.s (L-type karyotype). It means that chromosome size reduction occurred within the clade of Aster s.l. In addtion to the L-type and S-type karyotypes, LS-type karyotype, considered to be amphidiploid between them, is known in A. microcephalus (Miq.) Franch. et Sav. and its intraspecific taxa (Huziwara 1957b, Tara 1977). Ito et al. (1995 and 1998) supposed that A. ageratoides Turcz. var. ageratoides (designated as A. leiophyllus Franch. et Sav.) and A. iinumae Kitam. ex Hara (designated as $K$. pinnatifida (Matsum.) Makino) could be the parents of $A$. microcephalus var. ovatus (Franch. et Sav.) Soejima et Mot. Ito based on chloroplast DNA data.

Fluorescence in situ hybridization (FISH) with rDNA is a useful marker for chromosome identification, which provides the phylogenetic information of closely related taxa (e.g., Ansari et al. 1999, Singh 2001). In plant, FISH for ribosomal RNA genes have been widely used for karyotyping (Leitch and Heslop-Harrison 1993, Matoba et al. 2001, Raina et al. 2001, Hajdera et al. 2003, Navrátilová et al. 2003), and for studying genome organization and chromosome evolution within many genera (Ali et al. 2000, Anamthawat-Jónsson and Bödvarsdóttir 2001, Hasterok et al. 2001, Raina et al. 2001, Ran et al. 2001, Singh et al. 2001, Li and Zhang 2002). The gene for 18S-5.8S26S rRNA occur as a large number of tandem repeats that form a single transcription unit. Usually, these sequences are located in the NORs of eukaryotes (Long and Dawid 1980). The 5S rDNA is organized in tandem array with repeat units composed of a coding region, and generally located independently of 18S-5.8S-26S rRNA cluster in eukaryotes (Ansari et al. 1999). The physical mapping of these two rDNA greatly contribute to chromosomal identification in plant with small or morphologically similar chromosomes (Murata et al. 1997, Hastrok et al. 2002, Hajdera et al. 2003). Especially, McFISH is a powerful tool for the molecular cytogenetics, which allows simultaneous detection of several DNA probes.

Recently, Kokubugata et al. (2003) have determined the number of 18S rDNA loci in 2 species of Aster s. l., but they did not refer on the chromosomal evolution nor karyological homogeneity at all. The aim of this study is to investigate the chromosome homology between $A$. ageratoides var. ageratoides (referred as $A$. ageratoides hereafter), A. iinumaeand A. microcephalus var. ovatus (referred as $A$. microcephalus hereafter) using karyotyping and McFISH with 5S and 18S rDNA, and consider the mechanism of chromosomal evolution in Aster s. $l$.

\section{Materials and methods}

\section{Plant materials and chromosome preparation}

Aster ageratoides, A. iinumae and A. microcephalus were collected in Japan, and were cultivated in the Department of Plant Science, Kyushu Tokai University (Table 1). The seedlings were pretreated with $2 \mathrm{~mm} 8$-hydroxyquinoline at room temperature for $3 \mathrm{~h}$ before they were fixed in ethanol-acetic acid $(3: 1)$ at $4{ }^{\circ} \mathrm{C}$ for $24 \mathrm{~h}$. Chromosomal preparations were prepared by the modified method of Leitch and Heslop-Harrison (1992). Fixed seedlings were washed 3 times in distilled

Table 1. Plant materials

\begin{tabular}{|c|c|c|}
\hline Species & Collection & $\begin{array}{l}\text { Chromosome } \\
\text { number }\end{array}$ \\
\hline $\begin{array}{l}\text { Aster ageratoides Turcz. var. } \\
\text { ageratoides }\end{array}$ & $\begin{array}{l}\text { Japan: Mt. Kiyosumi, } \\
\text { Tenshinkominato T., Chiba Pref. }\end{array}$ & $2 n=18$ \\
\hline $\begin{array}{l}\text { A. iinumae Kitam. ex Hara } \\
\text { (= Kalimeris pinnatifida (Matsum.) } \\
\text { Kitam.) }\end{array}$ & Japan: Nishiurabara, Niigata Pref. & $2 n=18$ \\
\hline A. microcephalus var. ovatus & Japan: Kawanisi City, Hyougo Pref. & $2 n=36$ \\
\hline
\end{tabular}


water and their root-tips were cut into $2-3 \mathrm{~mm}$ long. Ten to thirty root-tips were placed in a microcentrifuge tube containing $500 \mu \mathrm{l}$ of enzyme solution (1\% Cellulase Onozuka-RS (Yakult Honsha) and $0.5 \%$ Pectolyase Y-23 (Kikkoman), $\mathrm{pH} 4.2$ ) and incubated at $37^{\circ} \mathrm{C}$ for $1 \mathrm{~h}$. They were washed 3 times with distilled water. Ten to $20 \mu$ of the fixative was dropped onto root-tip and air-dried.

\section{Chromosome classification}

Karyotype formulas at mitotic metaphase were based on the data of measurements of the chromosomes taken from the photographs. Chromosomes at mitotic metaphase were classified by arm ratio calculated by long arm/short arm following Levan et al. (1964): $\mathrm{m}=$ median-centromeric chromosome with arm ratio of $1.0-1.7$; $\mathrm{sm}=$ submedian-centromeric chromosome with arm ratio of $1.8-3.0 ; \mathrm{st}=$ subterminal-centromeric chromosome with arm ratio of $3.1-7.0, \mathrm{t}=$ terminal-centromeric chromosome with arm ratio 7.1 or more.

\section{PCR amplification of $5 S$ and $18 S$ ribosomal DNA}

Total genomic DNA was extracted according to the method of Shaw (1988) from young growing leaves of Aster ageratoides. PCR amplification of 5S and 18S rDNA followed the procedure of Hizume (1993) and Sogin (1990), respectively. The sequences of the primers were as follows: 5' CGGTGCATTAATGCTGGTAT-3' and 5'-CCATCAGAACTCCGCAGTTA-3' for the repeating units in 5S rRNA gene clusters, and 5'-AACCTGGTTGATCCTGCCAGT-3' and 5'-TGATCCTTCTGCAGGTTCACCTAC-3' for the $18 \mathrm{~S}$ rRNA coding regions. PCR reaction mixture (total $50 \mu \mathrm{l})$ contained $60 \mathrm{ng}$ of template DNA, $200 \mathrm{pmol}$ of each primer, $0.1 \mathrm{~mm}$ of each dNTP, $10 \mathrm{~mm}$ Tris- $\mathrm{HCl} \mathrm{pH} 8.3,50 \mathrm{~mm} \mathrm{KCl}, 1.5 \mathrm{mM} \mathrm{MgCl}_{2}$, and 1 unit of Taq polymerase (TOYOBO). Amplification was performed in a T1 Thermocycler (Biometra) programmed for 1 cycle of 4 min at $94{ }^{\circ} \mathrm{C}, 30$ cycles of $30 \mathrm{sec}$ at $94^{\circ} \mathrm{C}, 30 \mathrm{sec}$ at $60^{\circ} \mathrm{C}, 60 \mathrm{sec}$ at $72^{\circ} \mathrm{C}$, and 1 cycle of $5 \mathrm{~min}$ at $72{ }^{\circ} \mathrm{C}$.

\section{Fluorescence in situ hybridization (FISH)}

The $5 \mathrm{~S}$ and $18 \mathrm{~S}$ rDNA probes amplified by PCR were labeled by means of random primer DNA labeling with digoxgenin-dUTP (Takara) and nick translation with biotin-14-dATP (invitorogen), respectively, following the supplier's instructions. Labeled DNA probes were denatured at $95^{\circ} \mathrm{C}$ for $10 \mathrm{~min}$. Hybridization mixtures contained $50 \%$ formamide, $10 \%$ dextran sulfate and each probe at a concentration of $4 \mathrm{ng} / \mu \mathrm{l}$ in $2 \times \mathrm{SSC}$. $25 \mu \mathrm{l}$ of hybridization mixture was put on a chromosomal preparation and covered with a cover slip and sealed with rubber gum. The slides were denatured at $80^{\circ} \mathrm{C}$ for $3 \mathrm{~min}$ on a hot plate and then incubated overnight at $37^{\circ} \mathrm{C}$ in a humid chamber. After overnight incubation, coverslips were floated off in $2 \times \mathrm{SSC}$ and slides were rinsed in $2 \times \mathrm{SSC}$ at $42{ }^{\circ} \mathrm{C}$ for $10 \mathrm{~min}, 1 \times \mathrm{SSC}$ at $42{ }^{\circ} \mathrm{C}$ for $10 \mathrm{~min}$, and $2 \times \mathrm{SSC} / 0.2 \%$ Tween 20 at room temperature for $10 \mathrm{~min}$ twice. Slides were blocked with $5 \%(\mathrm{w} / \mathrm{v})$ bovine serum albumen in $2 \times \mathrm{SSC} / 0.2 \%$ Tween 20 for $10 \mathrm{~min}$ at room temperature. Signal was detected with $100 \mu \mathrm{l}$ of $5 \mu \mathrm{g} / \mathrm{ml}$ anti-digoxigeninrhodamine (Roche) and $2 \mu \mathrm{g} / \mathrm{ml}$ avidin-FITC (Roche) in $2 \times \mathrm{SSC}$ in each slide for $1 \mathrm{~h}$ at $37^{\circ} \mathrm{C}$ in a humid chamber. Slides were washed in $2 \times \mathrm{SSC} / 0.2 \%$ Tween 20 for $10 \mathrm{~min}$ twice, $2 \times \mathrm{SSC}$ at room temperature. The slides were then mounted in Vectashield Mounting Medium (Vector Lab.) containing $500 \mathrm{ng} / \mathrm{ml}$ of 4',6-diamidino-2-phenylinodole (DAPI).

\section{Results}

\section{Karyotype}

The chromosome number of Aster ageratoides was counted to be $2 n=18$ (Fig. 1A). The chromosomes of the complement in the species indicated a gradual decrease in length from the largest $(6.90 \mu \mathrm{m})$ to the shortest $(4.84 \mu \mathrm{m})$ chromosomes and consist of 2 sat-median-, 14 median- and 2 submedian-centromeric chromosomes (Fig. 2A). 


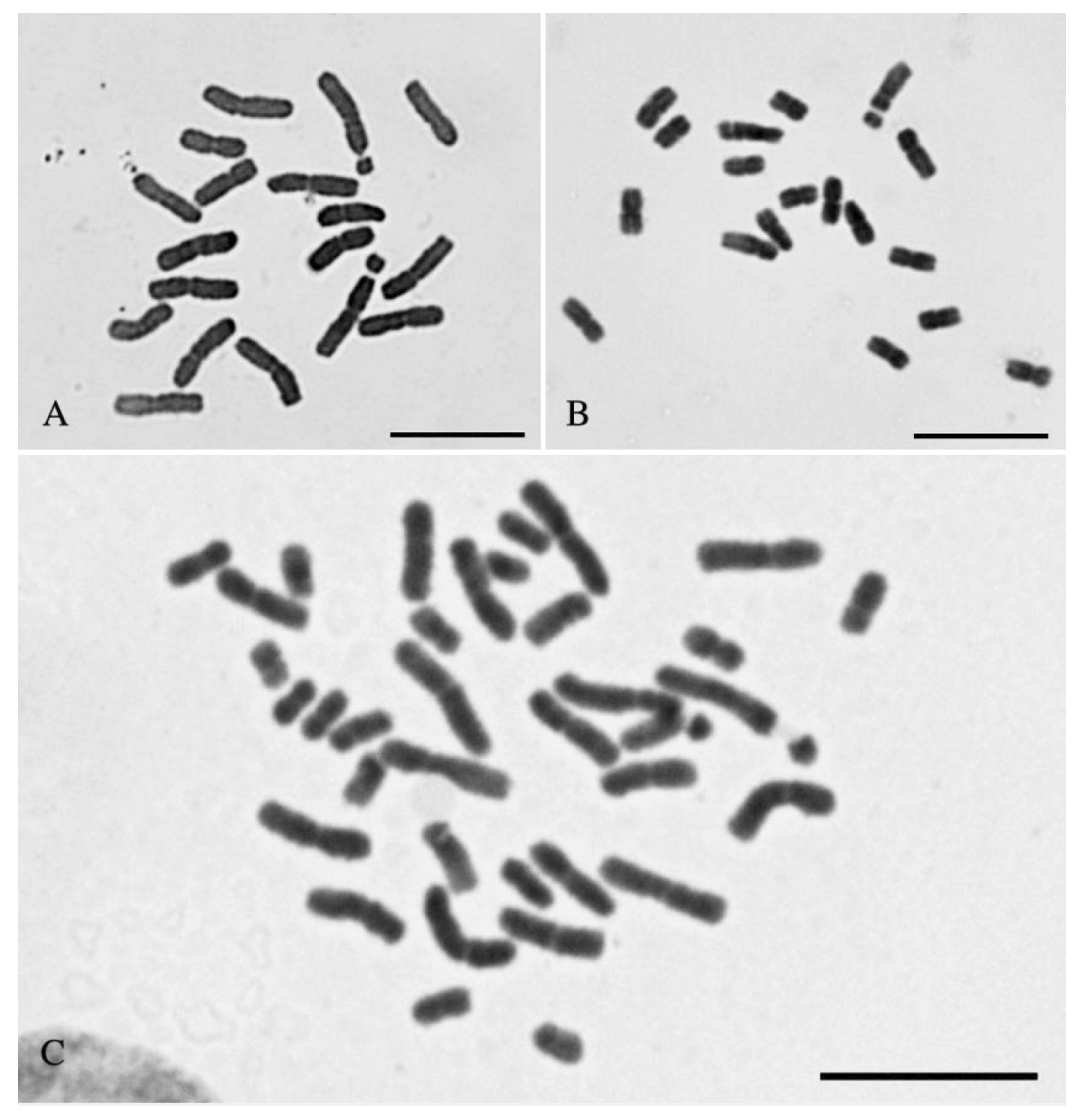

Fig. 1. Somatic metaphase chromosomes of 3 species of Aster. A: A. ageratoides var. ageratoides $(2 n=18)$. B: A. iinumae $(2 n=18)$. C: A. microcephalus var. ovatus $(2 n=36)$. Scale bar represents $10 \mu \mathrm{m}$ for A to C.

The chromosome number of $A$. iinumae counted here was $2 n=18$ (Fig. 1B). The chromosomes of the complement indicated a gradual decrease in length from the largest $(4.15 \mu \mathrm{m})$ to the shortest $(2.45 \mu \mathrm{m})$ chromosomes and consist of 2 sat-subterminal-, 14 median- and 2 submedian-centromeric chromosomes (Fig. 2B).

The chromosome number of $A$. microcephalus observed was $2 n=36$ (Fig. 1C). The chromosomes of the complement in the species showed bimodal distribution in length; larger ones were between $6.64-4.51 \mu \mathrm{m}$, the shorter ones between $3.27-1.88 \mu \mathrm{m}$, and consist of 2 sat-median-, 2 satsubterminal-, 28 median- and 4 submedian-centromeric chromosomes (Fig. 2C).

\section{FISH with $18 S$ and 5 S ribosomal DNA probes}

The chromosomal positions of 5S rRNA and 18S rRNA genes of A. ageratoides and A. iinumae were detected by McFISH. One pair of 5S rDNA site was at the interstitial region of the short arm of the submedian-centromeric chromosome in A. ageratoides (Fig. 3A), and the interstitial region of the short arm of the median-centromeric chromosome in A. iinumae (Fig. 3B). One pair of $18 \mathrm{~S}$ rDNA cluster was found in the secondary constriction on satellite chromosomes of each of the species (Figs. 3D and 3E). The McFISH of A. microcephalus chromosomes tagged 8 out of 36 chromosomes (Figs. 3C and 3F). The 5S rDNA were localized on the interstitial region of the short arm of one pair of the submedian-centromeric L-chromosomes and one pair of the median-centromeric S-chromosomes. A pair of $18 \mathrm{~S}$ rDNA sites was detected at the secondary constriction on L-satellite chromosomes and another pair was detected at the secondary constriction on S-satellite 


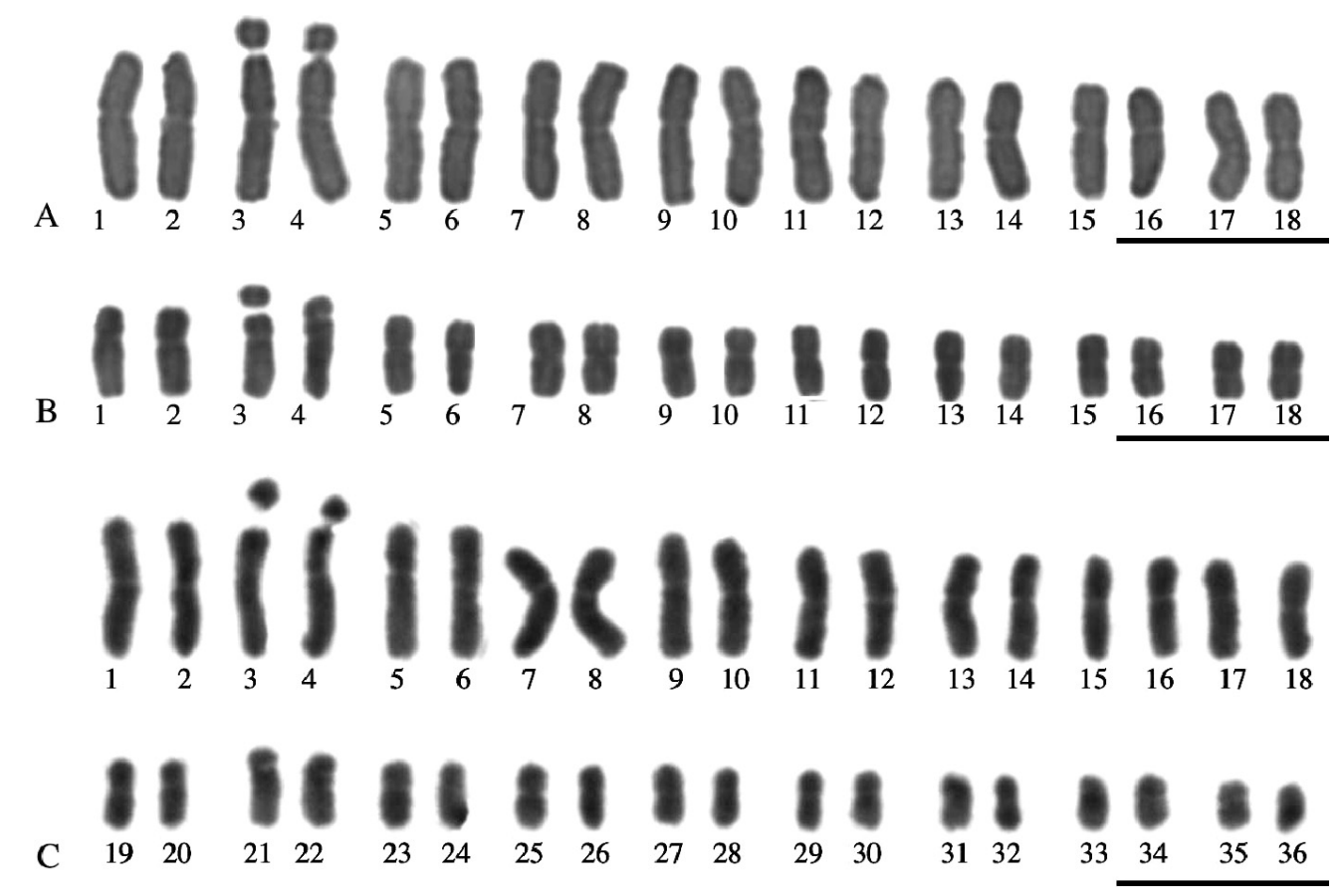

Fig. 2. Karyotypes of Aster species observed. A: A. ageratoides var. ageratoides $(2 n=18=18 \mathrm{~L})$. B: $A$. iinumae $(2 n=18=18 \mathrm{~S})$. C: A. microcephalus var. ovatus $(2 n=36=18 \mathrm{~L}+18 \mathrm{~S})$. Scale bar represents $10 \mu \mathrm{m}$ for $\mathrm{A}$ to $\mathrm{C}$.

chromosomes.

\section{Discussion}

The plants of Aster ageratoides and A. iinumae examined had the same chromosome number, $2 n=18$ (Fig. 1A and 1B), which implied diploid based on $x=9$. But there observed a significant difference in the chromosome size between $A$. ageratoides (L-type chromosomes) and A. iinumae (Stype chromosomes). The longest chromosome of $A$. iinumae $(4.15 \mu \mathrm{m})$ is shorter than the shortest one of $A$. ageratoides $(4.84 \mu \mathrm{m})$, and the total length of all the chromosomes of A. iinumae $(60.49 \mu \mathrm{m})$ is $55.4 \%$ of the latter $(109.1 \mu \mathrm{m})$. In spite of the critical difference in chromosome size, their karyotypes are relatively similar. One pair of satellite chromosomes could be easily recognized in each species, but the definitive identification of 14 median chromosomes of each species was difficult due to their similar chromosome lengths and arm ratios (Figs. 1C \& 1D). These results agreed with the previous reports (Huziwara 1957b and 1958, Shindo 1967, Tara 1977).

According to the molecular tree of Ito et al. (1995 and 1998), the large reduction of genome size has occurred on the evolutionary way to the several species called as Kalimeris which have short chromosomes. It is known that the genome size of plant species is greatly affected by the amounts of repetitive sequences and ploidy levels. The difference in the number of repetitive sequences contributes significantly to genome size, organization of chromosomes, and evolution of plant species (Bennetzen 2000). And it is also known that the difference of the amount of repetitive sequences could be caused by retrotransposons (Kamm et al. 1996, Galasso et al. 1997, HeslopHarrison et al. 1997, Vicient et al. 1999, Hanson et al. 2003). For example, retrotransposons showed more than $40 \%$ of the Vicia genome (Pearce et al. 1996) and more than $90 \%$ of the wheat genome (Flavell 1986). In these cases, retrotransposons caused increase in genome size. On the 


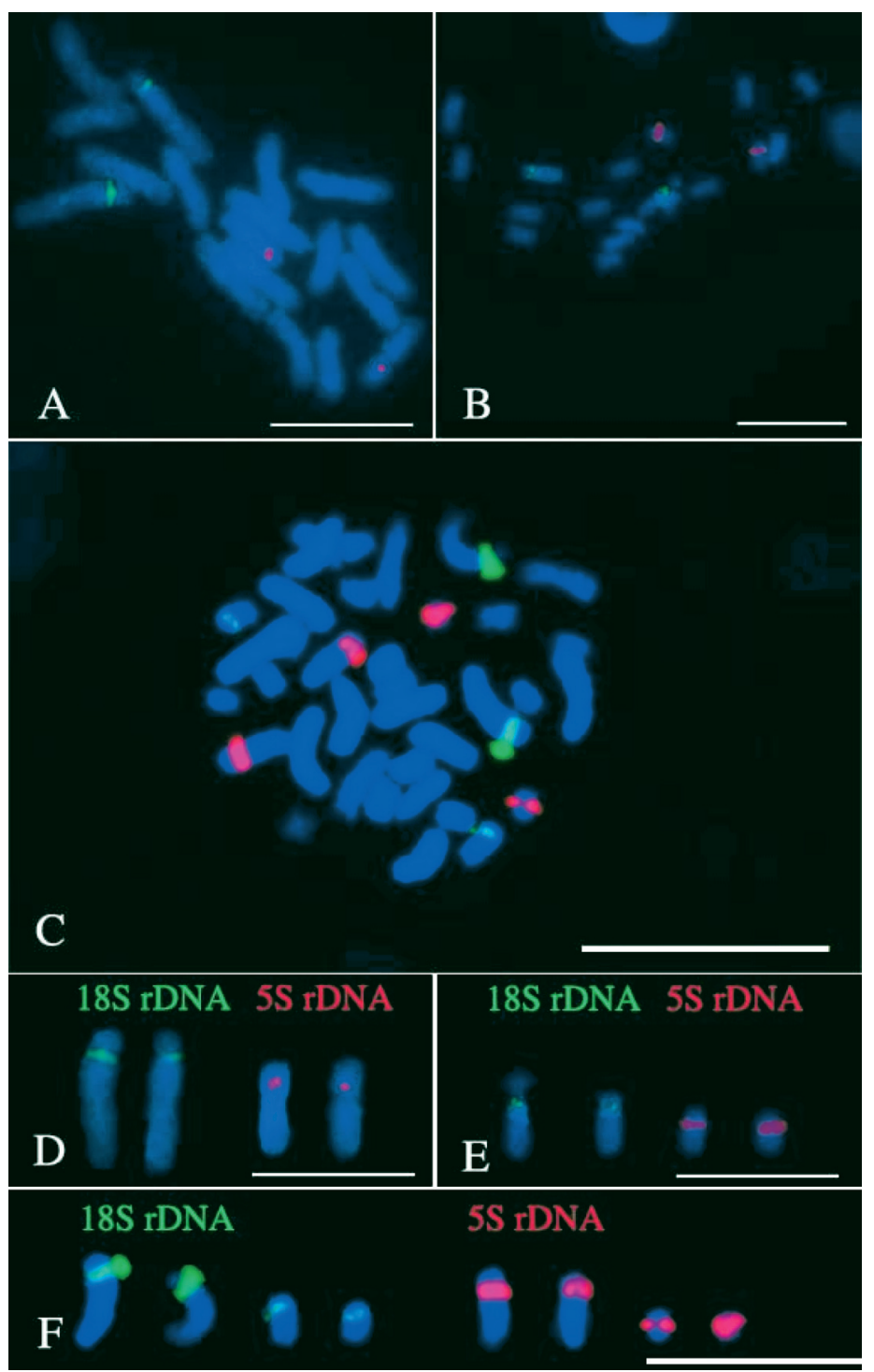

Fig. 3. Somatic metaphase chromosomes of Aster ageratoides var. ageratoides (A, D), A. iinumae (B, E) and $A$. microcephalus var. ovatus $(\mathrm{C}, \mathrm{F})$. A-C, Localization of rRNA gene by McFISH of 5S rDNA (red) and 18S rDNA (green) probes; D-F, Partial karyotype showing 18S rDNA and 5S rDNA carrying chromosomes. Chromosomes were counter stained with DAPI. Scale bar represents $10 \mu \mathrm{m}$ for A to $\mathrm{F}$.

other hand, the case in Aster s. $l$. mentioned above shows the genome size reduction, which is a relatively rare example in chromosome evolution. To resolve the mechanism of genome reduction in Aster s. l., to compare the chromosome structure between the both karyotypes is needed. In this study, the McFISH with 5S rDNA and 18S rDNA of A. ageratoides and A. iinumae chromosomes tagged 4 out of 18 chromosomes (Fig. 3). Chromosomal sites of 5S rDNA were on the short arms of the submedian-centromeric chromosomes in A. ageratoides, and on the short arms of the median centromeric chromosomes in A. iinumae. And the sites of $18 \mathrm{~S}$ rDNA were on the satellite chromosomes, which could be considered as homologous position in both species. The similarity of the karyotypes and the position of 18S rDNA sites may support the possibility that the reduction of the genome size was caused through a parallel miniaturization at least for the satellite chromosomes. 
To identify the chromosome homology between them, additional markers are required such as McFISH with bacterial artificial chromosomes and transformation-competent artificial chromosome as probes (Jiang et al. 1995, Hanson et al. 1995, Lapitan et al. 1997, Ohmido et al. 1998, Shen et al. 1998, Suzuki et al. 2001). And to elucidate the qualitative difference between them, measurement of DNA content is also necessary.

Tara (1977) suggested that $A$. microcephalus var. ovatus $(2 n=36)$ (referred as A. ageratoides subsp. ovatus) was a tetraploid amphidiploid produced by the combination of the L-type chromosomes of Aster and S-type chromosomes of Kalimeris. The chromosome number of A. microcephalus observed in this study was $2 n=36$, composed of LS-type chromosome set which is considered to be a combined set of $A$. ageratoides and $A$. iinumae (Figs. $1 \mathrm{C}$ and $2 \mathrm{C}$ ). The McFISH with 5S rDNA and 18S rDNA of $A$. microcephalus showed 2 pairs of 5S rDNA and 18S rDNA sites (Fig. 3C and 3F), respectively. Astermicrocephalus (LS-type karyotype) has 5S rDNA and 18S rDNA sites equal to the sum of the numbers of the 2 diploid species (A. ageratoides and A. iinumae) (Fig.3). One pairs of $18 \mathrm{~S}$ rDNA detected at the secondary constrictions of the each satellite chromosomes pair in L-type and S-type chromosome set (Fig. 3F). The 5S rDNA probes were hybridized 2 pairs of 2 different non-satellite chromosomes, one on the short arms of the submediancentromeric chromosomes in L-type chromosome set, and the other on the short arms of the median centromeric chromosomes in S-type chromosome set (Fig. 3F). Variability in number and distribution of $5 \mathrm{~S}$ and $18 \mathrm{~S}$ rRNA genes on chromosomes had been observed in several species and its relatives (Vaughan et al. 1993, Leggett and Markand 1995, Snowdon et al. 1997, Raina et al. 2001, Li and Zhang 2002). In this study, however, we demonstrated that the number and loci of 5S rDNA and $18 \mathrm{~S}$ rDNA had remained stable during the evolutionary process in chromosome reduction of Aster. Our results provide additional evidence for A. microcephalus being a tetraploid amphidiploid produced by the combination of Aster and Kalimeris.

\section{References}

Ali, H. B. M., Meister, A. and Schubert, I. 2000. DNA content, rDNA loci and DAPI bands reflect the phylogenetic distance between Lathyrus species. Genome 43: 1027-1032.

Anamthawat-Jónsson, K. and Bödvarsdóttir, S. K. 2001. Genomic and genetic relationships among species of Leymus (Poaceae: Triticeae) inferred from 18S-26S ribosomal genes. Amer. J. Bot. 88: 553-559.

Ansari, H. A., Ellison, N. W., Reader, M. S., Badaeva, E. D., Friebe, B., Miller, T. E. and Williams, W. M. 1999. Molecular Cytogenetic Organizations of 5S and 18S-26S rDNA Loci in White Clover (Trifolium repens L.) and Related Species. Amer. J. Bot. 83: 199-206.

Bennetzen, J. L. 2000. Transposable element contributions to plant gene and genome evolution. Plant. Mol. Biol. 42: 251-269.

Bremer, K. 1994. Asteraceae. Cladistics \& Classification. Timber Press, Portland.

Flavell, R. B. 1986. Repetitive DNA and chromosome evolution in plants. Philos. Trans. R. Soc. Lond. B. Biol. Sci. 312: 227-242.

Galasso, I., Harrison, G. E., Pignone, D., Brandes, A. and Heslop-Harrison, J. S. 1997. The distribution and organization of Ty1-copia-like retrotransposable elements in the genome of Vigna unguiculata (L.) Walp. (Cowpea) and its relatives. Ann. Bot. 80: 327-333.

Hajdera, I., Siwinska, D. and Hasterok, R. 2003. Molecular cytogenetic analysis of genome structure in Lupinus angustifolius and Lupinus cosentinii. Theor. Appl. Genet. 107: 988-996.

Hanson, L., Brown, R. L., Boyd, A., Johnson, M. A. T. and Bennett, M. D. 2003. First nuclear DNA C-values for 28 angiosperm genera. Ann. Bot. 91: 31-38.

Hanson, R. E., Zwick, M. S., Choi, S., Islam-Faridi, M. N., McKnight, T. D., Wing, R. A., Price, H. J. and Stelly, D. M. 1995. Fluorescent in situ hybridization of a bacterial artificial chromosome. Genome 38: 646-651.

Hasterok, R., Jenkins, G., Langdon, T., Jones, R. N. and Maluszynska, J. 2001. Ribosomal DNA is an effective marker of Brassica chromosomes. Theor. Appl. Genet. 103: 486-490.

—, Langdon, T., Taylor, S. and Jenkins, G. 2002. Combinatorial labeling of DNA probes enables multicolour fluorescence in situ hybridization in plants. Folia Histochem. Cytobiol. 40: 319-323.

Heslop-Harrison, J. S., Brandes, A., Taketa, S., Schmidt, T., Vershinin, A. V., Alkhimova, E. G., Kamm, A., Doudrick, R. L., Schwarzacher, T., Katsiotis, A., Kubis, S., Kumar, A., Pearce, S. R., Flavell, A. J. and Harrison, G. E. 1997. The chromosomal distribution of Ty1copia group retrotransposable elements in higher plants and their implications for genome evolution. Genetica 100: 197-204

Hizume, M. 1993. Chromosomal localization of 5S rRNA genes in Vicia fava and Crepis capillaris. Cytologia 58: 417-421.

Huziwara, Y. 1957a. Karyotype analysis in some genera of Compositae. II. The karyotype of Japanese Aster species. Cytologia 22: 96-112.

—. 1957b. Karyotype analysis in some genera of Compositae. III. The karyotype of the Aster aqeratoides group. Amer. J. Bot. 44: $783-790$.

- 1958. Karyotype analysis in some genera of Compositae. IV. The karyotypes within the genera Compositae. IV. The karyotypes within the genera Gymnaster, Kalineris and Heteropappus. Cytologia 23: 33-45. 
-. 1967. Chromosomal evolution in Aster and related genera. Taxon. 16: 303-304.

Ito, M., Soejima, A., Hasebe, M. and Watanabe, K. (1995). A Chloroplast-DNA Phylogeny of Kalimeris and Aster, with Reference to Generic Circumscription. J. Plant Res. 108: 93-96.

- , - , and Watanabe, K. 1998. Phylogenetic relationships of Japanese Aster (Asteraceae, Astereae) sensu lato based on chloroplast-DNA restriction site mutations. J. Plant Res. 111: 217-223.

Jiang, J., Gill, B. S., Wang, G. L., Ronald, P. C. and Ward, D. C. 1995. Metaphase and interphase fluorescence in situ hybridization mapping of the rice genome with bacterial artificial chromosomes. Proc. Natl. Acad. Sci. USA 92: 4487-4491.

Kamm, A., Doudrick, R. L., Heslop-Harrison, J. S. and Schmidt, T. 1996. The genomic and physical organization of Ty1-copia-like sequences as a component of large genomes in Pinus elliottii var. elliottii and other gymnosperms. Proc. Natl. Acad. Sci. USA 93:2708-2713.

Kitamura, S. 1937. Compositae Japonicae. I. Men. Coll. Sci. Kyoto Imp. Univ. Ser. B. 13: 337-357.

Kokubugata, G., Kondo, K., Tatarenko, I. V., Kulikov, P. V., Verkholat, V. P., Gontcharov, A., Ogura, H., Funamoto, T., Hoshi, Y. and Suzuki, R. 2003. Diploid cytogypes in two species of Aster sensu lato (Asteraceae) from Primorye Territory, Russia. Chrom. Sci. 7: 23-28.

Lapitan, N. L. V., Brown, S. E., Kennard, W., Stephens, J. L. and Knudson, D. L. 1997. FISH physical mapping with barley BAC clones. Plant J. 11: 149-156.

Leggett, J. M. and Markand, G. S. 1995. The genomic identification of some monosomics of Avena sativa L. cv. Sun using genomic in situ hybridization. Genome 38: 747-751.

Leitch, I. J. and Heslop-Harrison, J. S. 1992. Physical mapping of the 18S-5.8S-26S rRNA genes in barley by in situ hybridization. Genome 35: $1013-1018$.

—. and —. 1993. Physical mapping for four sites of 5S rDNA sequences and one side of the alpha-amylase gene in barley (Hordeum vulgare). Genome 36: 517-523.

Levan, A., Fredga, K. and Sandberg, A. A. 1964. Nomenclature for centromeric position on chromosome. Hereditas 52: 201-220.

Li, D. and Zhang, X. 2002. Physical Localization of the 18S-5.8S-26S rDNA and Sequence Analysis of ITS Regions in Thinopyrum ponticum (Poaceae: Triticeae): Implications for Concerted Evolution. Amer. J. Bot. 90: 445-452.

Long, E. O. and Dawid, B. 1980. Repeated genes in eukaryotes. Annu Rev. Biochem. 49: 727-764.

Matoba, H., Uchiyama, H. and Koyama, T. 2001. Physical mapping of 5S and 18S rDNA in lettuce, Lactuca sativa L. (Asteraceae). Chrom. Sci. 5: $73-77$.

Murata, M., Heslop-Harrison, J. S. and Motoyoshi, F. 1997. Physical mapping of the 5S ribosomal RNA genes in Arabidopsis thaliana by multi-color fluorescence in situ hybridization with cosmid clone. Plant J. 12: 31-37.

Navrátilová, A., Neumann, P. and Macas, J. 2003. Karyotype analysis of four Vicia species using in situ hybridization with repetitive sequences. Ann. Bot. 91: 921-926.

Ohmido, N., Akiyama, Y. and Fukui, K. 1998. Physical mapping of unique nucleotide sequences on identified rice chromosomes. Plant Mol. Biol. 38: 1043-1052.

Pearce, S. R., Harrison, G., Li, D., Heslop-Harrison, J. S. Kumar, A. and Flavell, A. J. 1996. The Ty1-copia group retrotransposons in Vicia species: copy number, sequence heterogeneity and chromosomal location. Mol. Gen. Genet. 250: 305-315.

Raina, S. N., Mukai, Y., Kawaguchi, K., Goel, S. and Jain, A. 2001. Physical mapping of 18-5.8-26S and 5S ribosomal RNA gene families in three important vetches (Vicia species) and their allied taxa consistuting three species complexes. Theor. Appl. Gnenet. 103: 839-845.

Ran, Y., Hammett, R. W. and Murray B. G. 2001. Phylogenetic Analysis and Karyotype Evolution in the Genus Clivia (Amaryllidaceae). Ann. Bot. 87: 823-830.

Richard, D. and Rieseberg, L.H. 1999. ITS sequence data support a single orgin for North American Astereae (Asteraceae) and reflect deep geographic divisions in Aster s. l. Amer. J. Bot. 83: 398-412.

Shaw, C. H. (ed.) 1988. Plant Molecular Biology. A Practical Approach. Oxford Univ. Press, Oxford.

Shen, K. A., Meyers, B. C., Islam-Faridi, M. N., Chin, D. B., Stelly, D. M. and Michelmore, R. W. 1998. Resistance gene candidates identified by PCR with degenerate oligonucleotide primers map to clusters of resistance genes in lettuce. Mol. Plant-Microbe Interact. 11: 815-823.

Shindo, K. 1967. Cytological, morphological and geographical studies on the differenciation of species in section Asteromoea of Kalimeris in Japan. J. Sci. Hiroshima Univ., Ser. B. Div. 2, 11: 127-199.

Singh, R. J., Kim, H. H. and Hymowitz, T. 2001. Distribution of rDNA loci in the genus Glycine Willd. Theor. Appl. Genet. 103: $212-218$.

Snowdon, R. J., Köhler, W. and Köhler, A. 1997. Chromosomal localization and chracterization of rDNA loci in the Brassica A and C genomes. Genome 40: 582-587.

Sogin, M. L. 1990. Amplification of ribosomal RNA genes for molecular evolution studies. In RCR Protocols. A Guide to Methods and Applications (eds. Innis, M. A., Gelfand, D. H., Sninsky, J. J. and White, T. J.), pp. 307-322, Academic Press, Inc.

Suzuki, G., Ura, A., Saito, N., Do, G.S., Seo, B.B., Yamamoto, M. and Mukai, Y. 2001. BAC FISH analysis in Allium cepa. Genes Genet. Syst. 76: $251-255$.

Tara, M. 1977. Cytologenetic studies on natural intergeneric hybridization on Aster alliances. IV. Experimental confirmation of the hybrid origin of Aster ageratoides subsp. ovatus. Bot. Mag. Tokyo 90: 253-258.

Vicient, C. M., Suoniemi, A., Anamthawat-Jónsson, K., Tanskanen, J., Beharav, A., Nevo, E. and Schulman, A. H. 1999. Retrotransposon BARE-1 and Its Role in Genome Evolution in the Genus Hordeum. 11: 1769-1784.

Vaughan, H. E., Jamilena, M., Ruiz Rejon, C., Parker, J. S. and Garrido-Ramos, M. A. 1993. Loss of nucleolus-organizer regions during polyploidy evokution in Schilla autumnalis. Heredity 71: 574-580. 